\title{
IDENTIFIKASI AKTINOMISETES SEDIMEN AIR TAWAR MAMASA, SULAWESI BARAT DAN AKTIVITASNYA SEBAGAI ANTIBAKTERI DAN PELARUT FOSFAT
}

\section{Identification of Actinomycetes in Freshwater Sediments from Mamasa, West Sulawesi and Their Antibacterial and Phosphate Solubilizing Activities}

\author{
Ade Lia Putri ${ }^{1, \star}$, Puspita Lisdiyanti ${ }^{2}$, Mia Kusmiati ${ }^{1}$ \\ ${ }_{1}^{1}$ Pusat Penelitian Biologi, LIPI, Cibinong 16911 Jawa Barat \\ 2Pusat Penelitian Bioteknologi, LIPI, Cibinong 16911 Jawa Barat \\ *Email: ade.lia.putri@lipi.go.id
}

\begin{abstract}
A large number of actinomycetes that have been isolated and screened were obtained from soil and marine samples. Consequently, the possibility of isolating novel Actinomycetes and secondary metabolites compounds strains from soil and marine samples have limited. Exploration of actinomycetes from freshwater sediment is rare. In this study, 30 isolates of Actinomycetes from freshwater sediments in Mamasa District, West Sulawesi were isolated, identified, and screened for their antibacterial and phosphate solubilizing activity. Actinomycetes were isolated by serial dilution method and were identified based on morphological and 16S rRNA gene sequence. Antibiotic activity was screened using the agar plug diffusion method, while soluble phosphate ability was observed by clear zone ratio in PKA medium. Most of the isolates belong to the genus Streptomyces (80\%). Out of 30 isolates, $56.6 \%$ showed antibacterial activity and $36.6 \%$ had potential as solubilizing phosphate which belong to genus Streptomyces, Actinomadura, and Kitasatospora.
\end{abstract}

Keywords: $16 S$ rRNA, Actinomycetes, antibacterial, freshwater sediment, phosphate solubilizing

\begin{abstract}
ABSTRAK
Sebagian besar aktinomisetes yang telah diisolasi dan dilakukan penapisan metabolit sekundernya berasal dari sampel tanah dan laut. Konsekuensinya, kesempatan untuk menemukan aktinomisetes jenis baru maupun yang menghasilkan metabolit sekunder baru dari tanah dan laut semakin berkurang. Eksplorasi aktinomisetes dari lingkungan lain seperti sedimen air tawar jarang dilakukan. Pada penelitian ini, 30 isolat aktinomisetes yang diisolasi dari sedimen air tawar di Kabupaten Mamasa, Sulawesi Barat, telah diidentifikasi dan dilakukan penapisan antibakteri dan kemampuan isolat dalam melarutkan fosfat. Aktinomisetes diisolasi dengan metode pengenceran secara langsung dan selanjutnya diidentifikasi secara morfologi dan molekular berdasarkan gen 16S rRNA. Metode yang digunakan dalam penapisan aktivitas antibakteri adalah agar plug diffusion method, sedangkan kemampuan aktinomisetes dalam melarutkan fosfat diuji dengan cara menumbuhkan isolat pada media PKA. Isolat yang paling banyak diisolasi termasuk ke dalam marga Streptomyces (80\%). Dari 30 isolat, 56,6\% isolat menunjukkan adanya aktivitas antibakteri dan $36,6 \%$ dari isolat berpotensi sebagai pelarut fosfat, yang termasuk ke dalam marga Streptomyces, Actinomadura, dan Kitasatospora.
\end{abstract}

Kata Kunci: 16S rRNA, Aktinomisetes, sedimen air tawar, antibakteri, pelarut fosfat 


\section{PENDAHULUAN}

Aktinomisetes merupakan bakteri Gram positif yang memiliki DNA genom dengan kandungan GC (Guanine-Cytocine) yang tinggi (Chavan et al. 2013). Aktinomisetes disebut juga sebagai filamentous bacteria karena ciri morfologi aktinomisetes lebih menyerupai cendawan berfilamen dengan membentuk spora dan miselium, namun struktur sel dan komposisi dinding sel aktinomisetes mirip dengan bakteria (Das et al. 2008). Aktinomisetes dapat hidup hampir di semua ekosistem dan distribusi paling luas pada ekosistem tanah sehingga disebut sebagai bakteri tanah. Selain di tanah, aktinomisetes juga ditemukan di sedimen perairan baik perairan darat maupun perairan laut. Aktinomisetes merupakan kelompok bakteri penting karena kemampuannya secara luas menghasilkan metabolit sekunder terutama antibiotik (Raja dan Prabakarana 2011). Antibiotik yang dihasilkan bisa berupa antibakteri, antifungi, antikanker dan antiprotozoa (Raja \& Prabakarana 2011; Jadon et al. 2014). Jenis antibiotik yang dihasilkan diantaranya sepalosporin (Antonio et al. 2012), streptomisin (Ram 2014), penisilin (Torresbacete et al. 2015) dan rifampisin (Spanogiannopoulos et al. 2012).

Selain sebagai sumber antibiotik, aktinomisetes juga dapat menghasilkan enzim. Enzim yang dapat dihasilkan oleh aktinomisetes diantaranya fosfatase, protease, selulase, lipase, xilanase, amilase, pektinase, fitase, dan peroksidase (Ghorbani-Nasrabadi et al. 2013; Prakash et al. 2013). Sampai saat ini, aktinomisetes yang dapat menghasilkan enzim termasuk ke dalam marga Streptomyces, Thermonospora, Actinomadura, Nocardiopsis, Thermoactinomycetes, dan Microbispora (Prakash et al. 2013).

Sejumlah besar aktinomisetes yang telah berhasil diisolasi dan dilakukan penapisan metabolit sekunder bersumber dari media tanah dan laut (Bull et al. 2000; Subramani dan Aalbersberg 2012). Kegiatan penapisan antibiotik pada saat ini sudah mulai memperhatikan ekologi dari mikroorganisme penghasil antibiotik. Pencarian metabolit sekunder dari ekologi yang berbeda serta dari kelompok selain Streptomyces (rare actinomycetes) terus dilakukan. Aktinomisetes yang diisolasi dari ekosistem berbeda, seperti daerah perairan air tawar diharapkan dapat menghasilkan jenis dan senyawa bioaktif baru.

Aktinomisetes selain berperan penting dalam siklus nutrisi dan dekomposisi di tanah juga berperan di perairan. Selain itu, aktinomisetes juga berperan dalam proses degradasi bahan-bahan kontaminan yang masuk ke dalam perairan air tawar, seperti limbah industri, limbah rumah tangga, maupun limbah pertanian (Widenfalk 2005). Berbagai jenis aktinomisetes juga berperan dalam mengurai pestisida yang masuk ke dalam perairan, salah satunya Streptomyces $s p$. yang dapat mendegradasi pestisida jenis lidan (Katagi 2013). Faktor lingkungan seperti faktor fisik dan kimiawi lingkungan akan mempengaruhi keragaman jenis dan fungsi dari mikrob termasuk aktinomisetes (Chavan et al. 2013; Chaudhary et al. 2013). Dalam penelitian ini akan diungkapkan jenis aktinomisetes yang diperoleh dari ekosistem perairan air tawar serta potensinya sebagai penghasil antibakteri dan pelarut fosfat.

Mikroorganisme pelarut fosfat (termasuk kelompok aktinomisetes) akan mengekresikan asam organik dalam proses pengasaman yang akan melepaskan fosfat terikat menjadi fosfat bebas. Asam organik yang dihasilkan bisa berupa asam glukonat, asam sitrat, asam asetat, asam suksinat, asam oksalat, asam malat dan asam glikosalik. Jenis asam organik yang dihasilkan tergantung pada sumber karbon dan jalur metabolik yang dilalui (Rajput et al. 2013; Jog et al. 2014). Jog et al. (2014) melaporkan bahwa Streptomyces mhcr0816 menghasilkan asam organik berupa asam malat dan glukonat melalui lintasan glyoxalate.

Tujuan dari penelitian ini adalah mengisolasi dan mengidentifikasi aktinomisetes dari sedimen air tawar di Kabupaten Mamasa, Sulawesi Barat dan melihat kemampuan isolat dalam menghasilkan senyawa antibakteri dan melarutkan fosfat. Selain itu, hasil penelitian dapat memberikan kontribusi terhadap data mikroorganisme Indonesia yang memiliki potensi dan akan dihimpun dalam data base mikroorganisme khususnya di Sulawesi yang akan diseleksi dan diregistrasi untuk disimpan di Indonesian Culture Collection (InaCC). 


\section{BAHAN DAN METODE}

\section{Pengambilan sampel dan Isolasi}

Sampel sedimen diambil di sekitar aliran sungai dan air terjun di daerah Sarambung, Desa Kondokbakaru, Kabupaten Mamasa, Provinsi Sulawesi Barat. Lokasi berada pada ketinggian berkisar antara 1601-1722 meter di atas permukaan laut (dpl), dengan suhu lingkungan pada saat pengambilan sampel $16^{\circ} \mathrm{C}$, dan $\mathrm{pH}$ berkisar 6,5-7. Sedimen diambil pada kedalaman $\pm 10 \mathrm{~cm}$. Sampel sedimen yang ada di daerah tersebut berupa pasir. Sedimen dikumpulkan ke dalam botol koleksi yang telah disterilisasi. Sebelum proses isolasi, sampel sedimen dikeringkan pada suhu $60^{\circ} \mathrm{C}$ selama 50 menit.

Metode isolasi yang digunakan adalah metode pengenceran secara langsung (Mohseni et al. 2013). Satu gram sampel dimasukkan ke dalam $9 \mathrm{~mL}$ akuades steril, dihomogenkan dengan vorteks selama 10 menit. Kemudian dilakukan pengenceran bertingkat sampai diperoleh pengenceran 104. Dari masing-masing larutan pengenceran selanjutnya sebanyak $0,2 \mathrm{~mL}$ disebar ke dalam media Humic Acid-Vitamin Agar (HVA) (Yamamura et al. 2003). Cawan petri selanjutnya diinkubasi pada suhu 28$30^{\circ} \mathrm{C}$ selama $14-21$ hari. Isolat aktinomisetes yang tumbuh dari proses isolasi diseleksi secara morfologi dan ditumbuhkan kembali pada media Yeast Starch Agar (YSA). Isolat murni kemudian disimpan pada suhu $-80^{\circ} \mathrm{C}$ dalam gliserol $10 \%$.

\section{Identifikasi berdasarkan analisis gen 16S rRNA}

DNA genom diekstraksi mengikuti metode Franco-Correa et al. (2010). Selanjutnya identifikasi dilakukan secara molekuler berdasarkan analisis gen 16S rRNA. Amplifikasi gen 16S rRNA menggunakan primer 27F (5' AGAGTTTGA TCCTGGCTCAG $\left.\quad 3^{\prime}\right)$ dan 1492R (5' GGTTACCTTGTTACGACTT 3'). Komposisi reaksi PCR yang digunakan adalah GoTaq ${ }^{\circledR}$ Green Master Mix 12,5 $\mu$; nuclease free water $10 \mu \mathrm{L}$; masing-masing primer (50 $\mathrm{ng} / \mu \mathrm{L}) \quad 0,5 \mu \mathrm{L}$; DMSO $0,5 \mu \mathrm{L}$; dan DNA template $1 \mu \mathrm{L}$. Kondisi PCR untuk mengamplifikasi fragmen gen 16S rRNA adalah predenaturasi $94^{\circ} \mathrm{C}$ selama 1 menit, denaturasi pada $95^{\circ} \mathrm{C}$ selama 30 detik, annealing pada suhu $50^{\circ} \mathrm{C}$ selama 30 detik, elongasi pada suhu $72^{\circ} \mathrm{C}$ selama 1 menit 30 detik diikuti tahapan pendinginan $4^{\circ} \mathrm{C}$ selama 15 menit. Proses dilakukan sebanyak 30 siklus. Sekuen nukleotida dilakukan dengan mengirimkan produk PCR ke penyedia jasa. Identifikasi jenis diperoleh dengan cara membandingkan antara nukleotida hasil sekuensing dengan database mikroorganisme pada laman http://www.ezbiocloud.net/eztaxon/ident berdasarkan data sekuen 16S rRNA (Kim et al. 2012).

\section{Penapisan aktivitas antibakteri}

Metode yang digunakan dalam penapisan aktivitas antibakteri adalah agar plug diffusion method (Balouiri et al. 2016). Bakteri target yang digunakan adalah Bacillus subtilis (InaCC B1), Escherichia coli (InaCC B5), dan Staphylococcus aureus (InaCC B4). Media uji antibakteri yang digunakan adalah Mueller Hinton (MH) (Sharma et al. 2011; Mohseni et al. 2013). Media $\mathrm{MH}$ dibuat dua lapis, lapisan atas merupakan media $\mathrm{MH}$ semi padat sebanyak $4 \mathrm{~mL}$, sedangkan lapisan bawah merupakan media $\mathrm{MH}$ padat sebanyak $15 \mathrm{~mL}$. Untuk membuat seed culture, masing-masing sebanyak 1 loop bakteri target diinokulasikan pada $5 \mathrm{~mL}$ media $\mathrm{MH}$ cair dan diinkubasi pada suhu $37^{\circ} \mathrm{C}$ menggunakan shaker inkubator selama 21 jam. Masing-masing sebanyak $B$. subtilis InaCC B1 $0,1 \%$; E. coli InaCC B5 0,2\%; dan S. aureus InaCC B4 $0,1 \%$ ditambahkan pada media $\mathrm{MH}$ lapisan atas sebelum dituang sebanyak $4 \mathrm{~mL}$ ke atas media $\mathrm{MH}$ lapisan bawah. Kultur aktinomisetes (umur 7-14 hari) dengan diameter $1 \mathrm{~cm}$ diletakkan di atas media $\mathrm{MH}$ lapisan atas. Aktivitas antibakteri diamati setelah media diinkubasi selama 24 jam pada suhu $37^{\circ} \mathrm{C}$. Aktivitas positif ditunjukkan dengan terbentuknya zona bening di sekitar koloni aktinomisetes. Indeks zona bening dihitung berdasarkan perbandingan antara diameter zona bening dan diameter koloni.

\section{Uji Potensi Isolat sebagai Pelarut Fosfat}

Isolat aktinomisetes dengan diameter koloni $1 \mathrm{~cm}$ yang berumur 14 hari ditumbuhkan pada media Pikovskaya agar (PKA). Komposisi media PKA adalah glukosa $10 \mathrm{~g} / \mathrm{L} ; \mathrm{Ca}_{3} \mathrm{PO}_{4} 5 \mathrm{~g} / \mathrm{L} ;\left(\mathrm{NH}_{4}\right)_{2} \cdot \mathrm{SO}_{4}$ $0,5 \mathrm{~g} / \mathrm{L} ; \mathrm{KCl} 0,2 \mathrm{~g} / \mathrm{L} ; \mathrm{MgSO}_{4} \cdot 7 \mathrm{H}_{2} \mathrm{O} 0,1 \mathrm{~g} / \mathrm{L} ;$ $\mathrm{MnSO}_{4} \cdot \mathrm{H}_{2} \mathrm{O} 0,01 \mathrm{~g} / \mathrm{L}$; ekstrak khamir 0,5 g/L; 
$\mathrm{FeCl}_{3} \cdot 6 \mathrm{H}_{2} \mathrm{O} 0,01 \mathrm{~g} / \mathrm{L} ;$ agar $18 \mathrm{~g} / \mathrm{L}$ dengan $\mathrm{pH}$ 7. Isolat aktinomisetes yang telah ditumbuhkan pada media PKA selanjutnya diinkubasi pada suhu $28^{\circ} \mathrm{C}$ selama 14 hari. Aktivitas positif ditunjukkan dengan terbentuknya zona bening di sekitar koloni aktinomisetes. Aktivitas pelarut fosfat ditentukan dengan perbandingan (rasio) antara diameter zona bening dan diameter koloni (Paul dan Sinha 2017).

\section{HASIL DAN PEMBAHASAN}

Total isolat aktinomisetes yang berhasil diisolasi dari sampel sedimen yang diambil di sekitar aliran sungai dan air terjun Sarambung di Kabupaten Mamasa, Sulawesi Barat adalah 30 isolat. Berdasarkan pengamatan morfologi, sebanyak 24 isolat menghasilkan miselium aerial dan sisanya sebanyak 6 isolat tidak membentuk miselium aerial.

Identifikasi aktinomisetes secara morfologi menjadi tahap awal untuk memisahkan marga aktinomisetes yang berhasil diisolasi. Beberapa karakter isolat yang diamati diantaranya miselium aerial, pigmen yang dihasilkan, warna koloni, dan warna masa spora ( $\mathrm{Li}$ et al. 2016). Namun demikian, identifikasi secara morfologi kadang tidak akurat, karena ada beberapa marga memiliki morfologi yang hampir sama, sehingga identifikasi dengan pendekatan molekular tetap diperlukan untuk mendapatkan informasi marga atau jenis isolat yang lebih akurat.

Isolat yang dapat menghasilkan

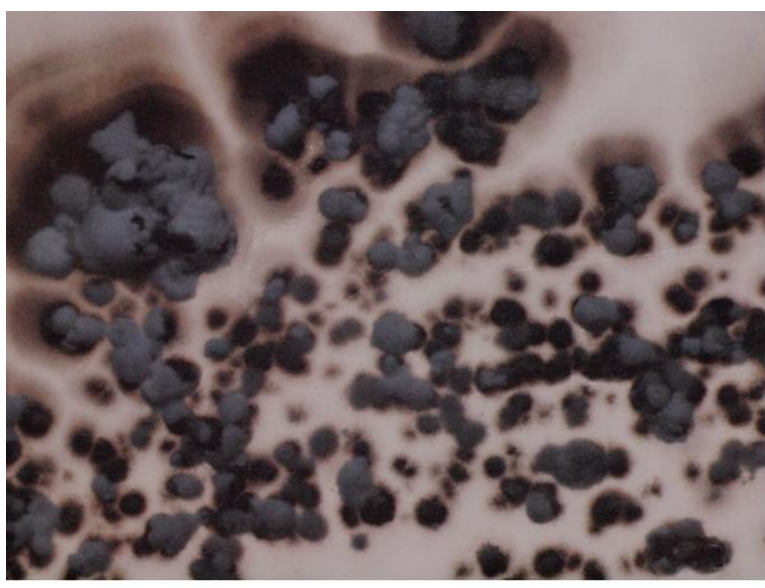

SBSD 1(3) pigmen hanya 2 isolat, yaitu kode SBSD 1(3) dan SBSD 7(1) (Gambar 1). Isolat SBSD 1(3) menghasilkan pigmen bewarna coklat keunguan sedangkan isolat SBSD 7(1) menghasilkan pigmen berwarna kuning setelah 21 hari ditumbuhkan di media YSA. Hasil identifikasi secara molekular menunjukkan bahwa isolat SBSD 1(3) diidentifikasi sebagai Kitasatospora purpeofusca dan isolat SBSD 7(1) diidentifikasi sebagai Streptomyces rhizosphaerihabitans.

Karakter morfologi yang ditunjukkan pada terbentuknya pigmen dalam media oleh aktinomisetes digunakan untuk identifikasi marga atau jenis, namun demikian munculnya pigmen sangat dipengaruhi oleh faktor lingkungan. Menurut Chater dan Chandra (2006), kemampuan spora bertahan dalam kondisi yang kurang menguntungkan pada beberapa jenis Streptomyces meningkatkan terbentuknya pigmen dan aroma yang dihasilkan oleh spora. Keadaan tersebut akan menstimulasi perkembangan sel dan terbentuknya metabolit sekunder yang dihasilkan (Chi et al. 2011). Selain itu, menurut $\mathrm{Chi}$ et al. (2011), nutrisi yang ada di lingkungan mempengaruhi perbedaan morfologi dan terbentuknya metabolit sekunder yang dihasilkan oleh Streptomyces.

Hasil identifikasi secara morfologi dan molekular menunjukkan bahwa isolat terbanyak yang berhasil diisolasi termasuk ke dalam marga Streptomyces yaitu sebanyak 24 isolat (80\%) (Tabel 1). Marga lain yang berhasil diisolasi adalah

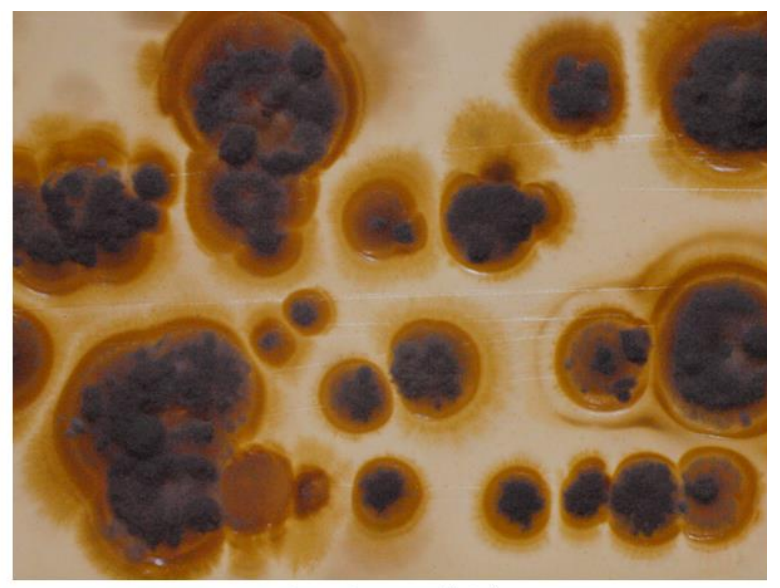

SBSD 7(1)

Gambar 1. Isolat SBSD 1 (3) dan Isolat SBSD 7 (1) yang menghasilkan pigmen ke dalam media. Isolat ditumbuhkan pada media YSA, umur 21 hari. Pengamatan menggunakan mikroskop stereo. 
Tabel 1. Keanekaragaman aktinomisetes yang berhasil diisolasi dari sedimen air tawar Mamasa, Sulawesi Barat

\begin{tabular}{|c|c|c|}
\hline Marga & Jenis & $\begin{array}{l}\text { Jumlah } \\
\text { isolat }\end{array}$ \\
\hline Actinomadura & $\begin{array}{l}\text { Actinomadura } \\
\text { oligospora }\end{array}$ & 1 \\
\hline \multirow{2}{*}{ Kitasatospora } & $\begin{array}{l}\text { Kitasatospora } \\
\text { aburaviensis }\end{array}$ & 1 \\
\hline & $\begin{array}{l}\text { Kitasatospora } \\
\text { purpeofusca }\end{array}$ & 1 \\
\hline Nocardia & Nocardia alba & 1 \\
\hline Rhodococcus & $\begin{array}{l}\text { Rhodococcus } \\
\text { maanshanensis }\end{array}$ & 2 \\
\hline \multirow{10}{*}{ Streptomyces } & $\begin{array}{l}\text { Streptomyces } \\
\text { adustus }\end{array}$ & 2 \\
\hline & $\begin{array}{l}\text { Streptomyces } \\
\text { aureus }\end{array}$ & 2 \\
\hline & $\begin{array}{l}\text { Streptomyces } \\
\text { avidinii }\end{array}$ & 2 \\
\hline & $\begin{array}{l}\text { Streptomyces } \\
\text { indigoferus }\end{array}$ & 1 \\
\hline & $\begin{array}{l}\text { Streptomyces } \\
\text { laculatispora }\end{array}$ & 1 \\
\hline & $\begin{array}{l}\text { Streptomyces } \\
\text { mirabilis }\end{array}$ & 1 \\
\hline & $\begin{array}{l}\text { Streptomyces } \\
\text { olivochromogenes }\end{array}$ & 2 \\
\hline & $\begin{array}{l}\text { Streptomyces } \\
\text { rhizosphaerihabitans }\end{array}$ & 4 \\
\hline & $\begin{array}{l}\text { Streptomyces } \\
\text { xanthophaeus }\end{array}$ & 1 \\
\hline & Streptomyces sp. & 8 \\
\hline \multicolumn{2}{|c|}{ Total } & 30 \\
\hline
\end{tabular}

Actinomadura sebanyak 1 isolat, Kitasatospora sebanyak 2 isolat, Nocardia sebanyak 1 isolat, dan Rhodococcus sebanyak 2 isolat (Tabel 1). Penelitian ini sama dengan penelitian sebelumnya bahwa Streptomyces sudah banyak ditemukan di ekosistem tanah (Raja dan Prabakarana 2011). Saat ini, lebih dari 500 jenis Streptomyces telah dideskripsikan (Raja dan Prabakarana 2011). Secara umum Streptomyces memiliki rantai spora di bagian ujung miselium aerial. Umumnya Streptomyces bersifat non-motil (Chater dan Chandra 2006; Otoguro et al. 2009; de Lima Procópio et al. 2012).

Sebanyak 17 isolat $(56,6 \%)$ menghasilkan antibakteri dan mampu menghambat pertumbuhan bakteri $E$. coli, $B$. subtilis, atau $S$. aureus (Tabel 2). Namun zona hambat yang dihasilkan tidak terlalu besar dengan rasio zona hambat yang terbentuk berkisar antara 1,2-2,7 (Tabel 2).
Sebanyak 16 isolat $(53,3 \%)$ mampu menghambat pertumbuhan E. coli, 8 isolat $(26,6 \%)$ mampu menghambat pertumbuhan $B$. subtilis dan 8 isolat $(26,6 \%)$ mampu menghambat pertumbuhan $S$. aureus (Tabel 2).

Hasil uji menunjukkan bahwa isolat aktinomisetes yang berhasil diisolasi dari sedimen air tawar lebih berpotensi dalam menghambat pertumbahan bakteri Gram negatif $(E$. colli) dibandingkan dengan bakteri Gram positif (B. subtilis dan S. aureus). Hal tersebut kemungkinan berhubungan dengan jenis bakteri yang sudah beradaptasi pada perairan tawar. Bakteri Gram negatif merupakan bakteri yang paling banyak ditemukan di perairan air tawar (Tamaki et al. 2005). Kurang lebih $47 \%$ bakteri yang berhasil diisolasi dari sedimen air tawar danau Eutropic termasuk ke dalam kelompok Proteobakteri yang umumnya merupakan bakteri Gram negatif (Tamaki et al. 2005). Hal tersebut memicu aktinomisetes yang hidup di lingkungan perairan untuk menghasilkan antibakteri yang dapat menghambat pertumbuhan bakteri Gram negatif, diantaranya E. coli.

Isolat yang dapat menghasilkan antibiotik diidentifikasi sebagai marga Streptomyces, Kitasatospora dan Actinomadura (Tabel 2). Isolat terbanyak yang dapat menghasilkan senyawa antibiotik termasuk ke dalam kelompok Streptomyces (14 isolat). Marga Streptomyces sudah banyak diketahui dapat menghasilkan antibiotik. Kurang lebih $80 \%$ antibiotik dihasilkan oleh aktinomisetes terutama marga Streptomyces (Raja dan Prabakarana 2011; Chaudhary et al. 2013). Sebanyak 7.600 senyawa dihasilkan oleh jenis Streptomyces. Streptomyses yang berbeda dapat menghasilkan kurang lebih 75\% antibiotik yang sudah dikomersialkan.

Dari 17 isolat yang diketahui berpotensi menghasilkan antibiotik, hanya dua isolat yang mampu menghambat pertumbuhan semua bakteri uji. Hal tersebut membuktikan bahwa kedua isolat uji dapat menghambat pertumbuhan bakteri Gram positif dan bakteri Gram negatif. Isolat tersebut adalah isolat SBSD 3(1) dan SBSD 3(2). Hasil identifikasi isolat terdekat menunjukkan bahwa isolat SBSD 3(1) homolog dengan Streptomyces xanthophaeus dan isolat SBSD 3(2) diidentifikasi sebagai Streptomyces sp. Hal 
Tabel 2. Aktinomisetes asal sedimen air tawar yang berpotensi menghasilkan antibiotik

\begin{tabular}{|c|c|c|c|c|c|}
\hline \multirow[b]{2}{*}{ No } & \multirow[b]{2}{*}{ Kode isolat } & \multirow[b]{2}{*}{ Hasil identifikasi isolat terdekat } & \multicolumn{3}{|c|}{ Rasio zona bening } \\
\hline & & & $\begin{array}{c}\text { Anti } \\
\text { E. coli }\end{array}$ & $\begin{array}{c}\text { Anti } \\
\text { B. subtilis }\end{array}$ & $\begin{array}{c}\text { Anti } \\
\text { S. aureus }\end{array}$ \\
\hline 1 & SBSD 01 (3) & Kitasatospora purpeofusca & & 1,2 & 1,5 \\
\hline 2 & SBSD 01 (4) & Streptomyces indigoferus & 1,7 & 1,3 & \\
\hline 3 & SBSD 01 (5) & Streptomyces rhizosphaerihabitans & 1,5 & & 1,6 \\
\hline 4 & SBSD 01 (6) & Streptomyces avidinii & 1,2 & & 1,5 \\
\hline 5 & SBSD $01(11)$ & Streptomyces avidinii & 1,3 & 2,0 & \\
\hline 6 & SBSD 01 (13) & Streptomyces aureus & 1,2 & & \\
\hline 7 & SBSD 03 (1) & Streptomyces xanthophaeus & 1,2 & 2,7 & 1,2 \\
\hline 8 & SBSD 03 (2) & Streptomyces sp. & 1,5 & 2,2 & 1,5 \\
\hline 9 & SBSD 03 (3) & Streptomyces sp & 1,2 & 1,7 & \\
\hline 10 & SBSD 03 (5) & Streptomyces rhizosphaerihabitans & 1,3 & 1,3 & \\
\hline 11 & SBSD 05 (1) & Kitasatospora aburaviensis & 1,3 & & 1,2 \\
\hline 12 & SBSD 05 (2) & Streptomyces sp. & 1,3 & & \\
\hline 13 & SBSD 07 (1) & Streptomyces rhizosphaerihabitans & 1,7 & & 1,4 \\
\hline 14 & SBSD 07 (2) & Streptomyces olivochromogenes & 1,7 & & \\
\hline 15 & SBSD 07 (3) & Streptomyces olivochromogenes & 1,5 & & \\
\hline 16 & SBSD $08(2)$ & Streptomyces mirabilis & 1,2 & 1,5 & \\
\hline 17 & SBSD 08 (4) & Actinomadura oligospora & 1,3 & & 1,3 \\
\hline
\end{tabular}

Tabel 3. Aktinomisetes asal sedimen air tawar yang dapat melarutkan fosfat

\begin{tabular}{|c|c|c|c|}
\hline No & Kode isolat & Hasil identifikasi isolat terdekat & Rasio zona bening \\
\hline 1 & SBSD 01 (5) & Streptomyces rhizosphaerihabitans & 2,1 \\
\hline 2 & SBSD 02 (1) & Streptomyces rhizosphaerihabitans & 2,3 \\
\hline 3 & SBSD 03 (1) & Streptomyces xanthophaeus & 2,1 \\
\hline 4 & SBSD 03 (2) & Streptomyces sp. & 2,3 \\
\hline 5 & SBSD 05 (1) & Kitasatospora aburaviensis & 2,1 \\
\hline 6 & SBSD 07 (1) & Streptomyces rhizosphaerihabitans & 2,3 \\
\hline 7 & SBSD 07 (2) & Streptomyces olivochromogenes & 2,4 \\
\hline 8 & SBSD 07 (3) & Streptomyces olivochromogenes & 2,1 \\
\hline & SBSD 08 (2) & Streptomyces mirabilis & 2,1 \\
\hline & SBSD 08 (3) & Streptomyces sp. & 2,4 \\
\hline & SBSD 08 (4) & Actinomadura oligospora & 2,1 \\
\hline
\end{tabular}

yang sama juga pernah dilaporkan oleh Singh et al. (2016) bahwa Streptomyces xanthophaeus dapat menghasilkan antibiotik. Berbagai senyawa metabolit yang dapat dihasilkan $S$. xanthophaeus seperti postprolin endopeptidase, benarthin, $\beta$ galactosidase (Singh et al. 2016).

Beberapa jenis aktinomisetes, diantaranya Streptomyces griseus pernah dilaporkan menghasilkan antibiotik streptomisin (Meanwell dan Shama 2008; Ram 2014). Streptomyces kanamyceticus menghasilkan kanamisin (Gao et al. 2017). Streptomyces menghasilkan rifampisin (Spanogiannopoulos et al. 2012) serta Streptomyces clavuligerus dapat menghasilkan $\beta$-lactam (Antonio et al. 2012). Selain menghasilkan senyawa antibakteri, isolat yang berhasil diisolasi juga dapat melarutkan fosfat terbukti dengan terbentuknya zona bening di sekitar media. Jumlah isolat yang dapat melarutkan fosfat sebanyak 11 isolat (36,6\%). Rata-rata indeks zona bening yang dihasilkan berkisar antara 2,1-2,4 (Tabel 3). Isolat yang dapat melarutkan fosfat termasuk ke dalam marga Streptomyces, Actinomadura, dan Kitasatospora. Marga dominan yang dapat melarutkan fosfat termasuk ke dalam marga Streptomyces.

Terbentuknya zona bening yang dihasilkan mengindikasikan bahwa isolat 
tersebut dapat melarutkan fosfat anorganik berupa trikalsium fosfat $\left(\mathrm{Ca}_{3}(\mathrm{PO} 4)\right)$ yang terdapat dalam media Pikovskaya. Terbentuknya zona bening yang dihasilkan di sekitar koloni bisa disebabkan oleh aktivitas enzim fosfatase yang dihasilkan atau karena produksi asam organik atau polisakarida yang dihasilkan oleh aktinomistes (Halder dan Chakrabartty 1993: Paul dan Sinha 2013a; Paul dan Sinha 2013b; Paul dan Sinha 2017). Jog et al (2014) melaporkan bahwa Streptomyces mhcr0816 menghasilkan asam malat (50-55 $\mathrm{mmol} / \mathrm{L}$ ) yang dapat melarutkan sebanyak $1916 \mathrm{mg}$ fosfat anorganik yang melibatkan kerja enzim.

Secara umum fosfat di dalam sedimen ada dalam bentuk organik dan anorganik yang tidak terlarut. Konsentrasi fosfat di dalam air sangat dipengaruhi oleh berbagai faktor. Ion fosfat paling banyak teradsorbsi oleh sedimen yang berlumpur dan sedimen jenis tanah liat (Sahu et al. 2007). Bakteri pelarut fosfat memiliki peran penting dalam proses pertukaran fosfor di dalam air dan sedimen.

Sahu et al. (2007) melaporkan bahwa 7 isolat aktinomisetes yang diisolasi dari sedimen tanah liat dan sedimen pasir di muara Vellar memiliki kemampuan dalam melarutkan fosfat. Aktifitas pelarut fosfat isolat aktinomisetes tertinggi diperoleh dari isolat yang diisolasi dari sedimen tanah liat. Isolat yang menghasilkan aktivitas pelarut fosfat tertinggi dihasilkan oleh isolat PS-3

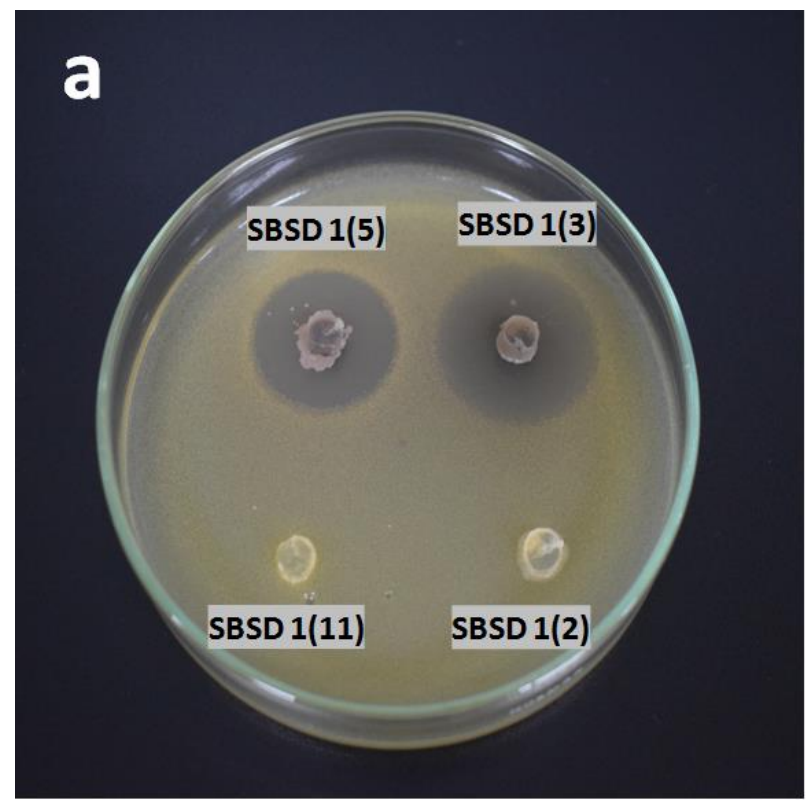

yang diidentifikasi sebagai Streptomyces galbus (Sahu et al. 2007). Kebutuhan fosfat mikroorganisme yang hidup di dalamnya terpenuhi dengan cara melarutkan fosfat terikat secara enzimatis (Sahu et al. 2007).

Isolat terbanyak yang berhasil diisolasi dan memiliki potensi sebagai pelarut fosfat memiliki homolog dengan Streptomyces rhizosphaerihabitans strain JR-35(T). Selain dapat melarutkan fosfat, jenis ini juga dapat menghasilkan senyawa antibiotik yang menghambat pertumbuhan $E$. coli dan $B$. subtilis. S. rhizosphaerihabitans strain JR35(T) merupakan aktinomisetes jenis baru yang ditemukan oleh Lee dan Whang (2016). Jenis ini berhasil diisolasi dari tanah hutan bambu. Belum ada laporan tentang ditemukannya jenis ini di perairan air tawar. Selain itu, informasi tentang potensi jenis ini baik dalam menghasilkan senyawa antibiotik maupun metabolit sekunder belum pernah dilaporkan. Isolat-isolat yang telah diidentifikasi dengan baik selanjutnya diseleksi, diregistrasi dan disimpan di Indonesian Culture Collection (InaCC).

Selama ini aktinomisetes telah banyak ditemukan pada sampel tanah dan sedimen laut dan sudah dimanfaatkan untuk penemuan antibiotik ataupun enzim (Bull et al. 2000, Subramani dan Aalbersberg 2012). Beberapa publikasi juga melaporkan bahwa aktinomisetes dapat ditemukan di tanah yang dekat dengan air terjun ataupun gua di taman nasional di Bangladesh, Malaysia dan Thailand (Han et al. 2013; Sripreechasak et

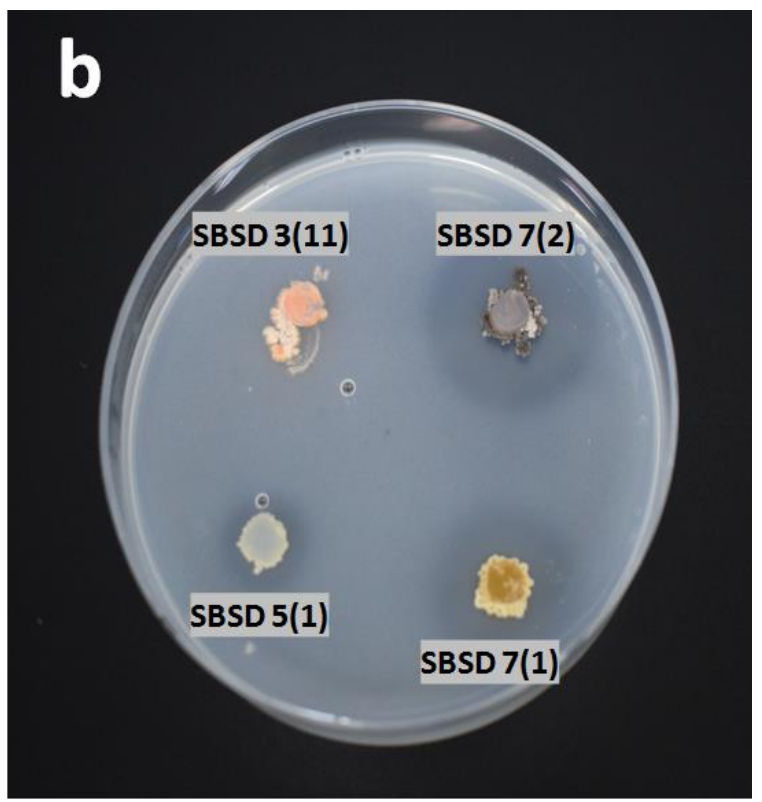

Gambar 2. Kemampuan aktinomisetes menghasilkan antibakteri (a) dan sebagai pelarut fosfat (b). 
al. 2013; Sripreechasak et al. 2017). Penelitian ini menunjukkan bahwa aktinomisetes yang ditemukan lebih banyak berperan dalam menghasilkan antibakteri dibandingkan sebagai pelarut fosfat.

\section{KESIMPULAN}

Tiga puluh isolat berhasil diisolasi dari sedimen perairan Mamasa, Sulawesi Barat. Dari jumlah tersebut yang menghasilkan pigmen adalah isolat isolat SBSD 1(3) yang menghasilkan pigmen berwarna coklat keunguan dan isolat SBSD 7(1) yang menghasilkan pigmen berwarna kuning. Hasil identifikasi isolat terdekat menunjukkan bahwa isolat SBSD 1(3) diidentifikasi sebagai Kitasatospora purpeofusca dan isolat SBSD 7(1) diidentifikasi sebagai Streptomyces rhizosphaerihabitans. Sebesar $80 \%$ isolat yang berhasil diisolasi termasuk ke dalam marga Streptomyces. Sebanyak $56,6 \%$ isolat menghasilkan antibakteri dan mampu menghambat pertumbuhan bakteri E. coli, B. subtilis, atau S. aureus. Hanya dua isolat yang mampu menghambat pertumbuhan semua bakteri uji yaitu isolat SBSD 3(1) dan SBSD 3(2). Sebanyak 36,6\% isolat dapat melarutkan fosfat dengan indek zona bening berkisar 2,1 - 2,4. Aktinomisetes yang berhasil ditemukan dari sedimen air tawar Mamasa memiliki potensi menghasilkan senyawa antibiotik dan berpotensi pelarut fosfat, yang diharapkan dapat digunakan untuk studi selanjutnya.

\section{UCAPAN TERIMAKASIH}

Penelitian ini merupakan hasil eksplorasi E-WIN (Ekspedisi Widya Nusantara) LIPI tahun 2016. Ucapan terimakasih penulis ucapkan kepada Bapak Prof. Rosichon Ubaidillah yang membimbing dalam penulisan, serta Ruby Setiawan, Rini Riffiani, Dian Alfian Nurcahyanto, dan Gita Azizah Putri atas bantuannya selama penelitian.

\section{DAFTAR PUSTAKA}

Antonio $\mathrm{T}$, Bellão $\mathrm{C}$, Corrêa $\mathrm{T}$, Cavallieri AP, Badino AC, Araujo MLGC (2012) Evaluation of different media for the production of cephalosporins by Streptomyces clavuligerus ATCC
27064. Braz Arch Biol Technol 55:819-825. doi: 10.1590/S151689132012000600003

Balouiri M, Sadiki M, Ibnsouda SK (2016) Methods for in vitro evaluating antimicrobial activity: A review. J Pharm Anal 6:71-79. doi: 10.1016/j.jpha.2015.11.005

Bull AT, Ward AC, Goodfellow M (2000) Search and discovery strategies for biotechnology: the paradigm shift. Microbiol Mol Biol Rev 64:573-606

Chater KF, Chandra G (2006) The evolution of development in Streptomyces analysed by genome comparisons. FEMS Microbiol Rev 30:651-672. doi: 10.1111/j.1574-6976.2006.00033.x

Chaudhary HS, Soni B, Shrivastava AR, Shrivastava S (2013) Diversity and versatility of actinomycetes and its role in antibiotic production. $\mathrm{J}$ Appl Pharm Sci 3:S83-S94. doi: 10.7324/JAPS.2013.38.S14

Chavan DV, Mulaje SS, Mohalkar RY (2013) A review on actinomycetes and their biotechnological application. Int J Pharmaceut Sci Res 4:1730-1742. doi: 10.13040/IJPSR.09758232.4(5).1730-42

Chi WJ, Lee SY, Lee J (2011) Functional analysis of SGR4635-induced enhancement of pigmented antibiotic production in Streptomyces lividans. J Microbiol 49:828-833. doi: 10.1007/s12275-011-1100-7

Das S, Lyla PS, Khan SA (2008). Distribution and generic composition of culturable marine actinomycetes from the sediments of Indian continental slope of Bay of Bengal. Chin J Oceanol Limnol 26:166-177. doi: 10.1007/s00343-008-0166-5

de Lima Procópio RE, da Silva IR, Martins MK, Azevedo JL, Araújo JM (2012) Antibiotics produced by Streptomyces. Braz J Infect Dis 16:466-471. doi: 10.1016/j.bjid.2012.08.014

Franco-Correa M, Quintana A, Duque C, Suarez C, Rodríguez MX, Barea JM (2010) Evaluation of actinomycete strains for key traits related with plant growth promotion and mycorrhiza helping activities. Appl Soil Ecol 45:209-217. doi: 10.1016/j.apsoil.2010.04.007 
Gao W, Wu Z, Sun J, Ni X, Xia H (2017) Modulation of kanamycin $B$ and kanamycin A biosynthesis in Streptomyces kanamyceticus via metabolic engineering. PLoS One. 12(7):e0181971. doi: 10.1371/journal.pone.0181971

Ghorbani-Nasrabadi R, Greiner R, Alikhani HA, Hamedi J, Yakhchali B (2013) Distribution of actinomycetes in different soil ecosystems and effect of media composition on extracellular phosphatase activity. J Soil Sci Plant Nutr 13:223-236. doi: 10.4067/S071895162013005000020

Halder AK, Chakrabartty PK (1993) Solubilization of inorganic phosphate by Rhizobium. Folia Microbiol 38:325330. doi: 10.1007/BF02898602

Han NY, Yi TJ, Chia YT (2013) Antimicrobial activity of actinomycetes isolated from Paya Maga, Sarawak. Jurnal Teknologi (Sciences and Engineering) 62:17-19. doi: 10.11113/jt.v62.1872

Jadon R, Singh V, Chaudhary HS (2014) Update on bioactive molecules of actinomycetes.

Biosciences Biotechnology Research Asia 11:705714. doi: $10.13005 /$ bbra/1325

Jog R, Pandya M, Nareshkumar G, Rajkumar S (2014) Mechanism of phosphate solubilization and antifungal activity of Streptomyces spp. isolated from wheat roots and rhizosphere and their application in improving plant growth. Microbiology 160:778-788. doi: 10.1099/ mic. $0.074146-0$

Katagi T (2013) Aerobic microbial transformation of pesticides in surface water. J Pestic Sci 38:10-26. doi: 10.1584/jpestics.D12-053

Kim OS, Cho YJ, Lee K, Yoon SH, Kim M, $\mathrm{Na} \mathrm{H}$, Park SC, Jeon YS, Lee JH, Yi $\mathrm{H}$, Won S, Chun J (2012) Introducing EzTaxon-e: a prokaryotic 16S rRNA gene sequence database with phylotypes that represent uncultured species. Int J Syst Evol Microbiol 62:716-721. doi: 10.1099/ijs.0.038075-0

Lee HJ, Whang KS (2016) Streptomyces rhizosphaerihabitans sp. nov. and Streptomyces adustus sp. nov., isolated from bamboo forest soil. Int $\mathrm{J}$
Syst Evol Microbiol 66:3573-3578. doi: 10.1099/ijsem.0.001236

Li Q, Chen X, Jiang Y, Jiang C (2016) Morphological identification of Actinobacteria. Chapter 3. In Dhanasekaran $D$ and Jiang $Y(E d)$. Actinobacteria: Basics and Biotechnological Applications. IntechOpen, London. doi: 10.5772/61461

Meanwell RJL, Shama G (2008) Production of streptomycin from chitin using Streptomyces griseus in bioreactors of different configuration. Bioresource Technology 99:5634-5639. doi: 10.1016/j.biortech.2007.10.036

Mohseni M, Norouzi H, Hamedi J, Roohi A (2013) Screening of antibacterial producing actinomycetes from sediments of the Caspian Sea. Int $\mathrm{J}$ Mol Cell Med 2:64-71

Otoguro M, Ratnakomala S, Lestari Y, Hastuti RD, Triana E, Widyastuti $Y$, Ando K (2009) Streptomyces baliensis sp. nov., isolated from Balinese soil. Int J Syst Evol Microbiol 59:21582161. doi: 10.1099/ijs.0.007179-0

Paul D, Sinha SN (2013a) Isolation of phosphate solubilizing bacteria and total heterotrophic bacteria from river water and study of phosphatase activity of phosphate solubilizing bacteria. Adv Appl Sci Res 4:409-412

Paul D, Sinha SN (2013b) Phosphate solubilization potential and phosphatase activity of some bacterial strains isolated from thermal power plant effluent exposed water of river Ganga. CIBTech J Microbiol 2:1-7

Paul D, Sinha SN (2017) Isolation and characterization of phosphate solubilizing bacterium Pseudomonas aeruginosa KUPSB12 with antibacterial potential from river Ganga, India. Annals of Agrarian Science 15:130-136. doi: 10.1016/ j.aasci.2016.10.001

Prakash D, Nawani N, Prakash M, Bodas M, Mandal A, Khetmalas M, Kapadnis B (2013) Actinomycetes: A repertory of green catalysts with a potential revenue resource. BioMed Res Int 18. doi: $10.1155 / 2013 / 264020$

Raja A, Prabakarana P (2011) Actinomycetes and drug - An 
overview. Am J Drug Discov Develop 1:75-84. doi: 10.3923/ajdd.2011.75.84

Rajput MS, Naresh KG, Rajkumar S (2013) Repression of oxalic acid-mediated mineral phosphate solubilization in rhizospheric isolates of Klebsiella pneumoniae by succinate. Arch Microbiol 195:81-88. doi: 10.1007/s00203-012-0850-x

Ram L (2014) Optimization of medium for the production of Streptomycin by Streptomyces griseus. Int J Pharmaceut Sci Invention 3:1-8

Sahu MK, Sivakumar K, Thangaradjou T, Kannan L (2007) Phosphate solubilizing actinomycetes in the estuarine environment: An inventory. J Environ Biol 28:795-798

Sharma D, Kaur T, Chadha BS, Manhas RK (2011) Antimicrobial activity of actinomycetes against multidrug resistant Staphylococcus aureus, $E$. coli and various other pathogens. Trop J Pharm Res 10:801-808. Doi: 10.4314/tjpr.v10i6.14

Singh V, Haque S, Singh H, Verma J, Vibha $\mathrm{K}$, Singh $\mathrm{R}$, Jawed A, Tripathi CKM (2016) Isolation, screening, and identification of novel isolates of actinomycetes from India for antimicrobial applications. Front Microbiol 7:1921. doi: 10.3389/fmicb.2016.01921

Spanogiannopoulos $\mathrm{P}$, Thaker M, Koteva K, Waglechner N, Wright GD (2012) Characterization of a rifampininactivating glycosyltransferase from a screen of environmental actinomycetes. Antimicrob Agents Chemother 56:5061-5069. doi: 10.1128/AAC.01166-12

Sripreechasak $P$, Matsumoto $A$, Suwanborirux K, Inahashi $\mathrm{Y}$, Shiomi K, Tanasupawat S, Takahashi Y (2013) Streptomyces siamensis sp. nov., and Streptomyces similanensis sp. nov., isolated from Thai soils. J antibiot 66:633-640. doi: 10.1038/ja.2013.60

Sripreechasak P, Phongsopitanun W, Tamura T, Tanasupawat S (2017) Streptomyces krungchingensis sp. nov., isolated from soil. Int $\mathrm{J}$ Syst Evol Microbiol 67:50-54. doi: 10.1099/ijsem.0.001570

Subramani R, Aalbersberg W (2012) Marine actinomycetes: An ongoing source of novel bioactive metabolites. Microbiol Res 167:571-580. doi: 10.1016/j.micres.2012.06.005

Tamaki H, Sekiguchi Y, Hanada S, Nakamura K, Nomura N, Matsumura M, Kamagata Y (2005) Comparative analysis of bacterial diversity in freshwater sediment of a shallow eutrophic lake by molecular and improved cultivation-based techniques. Appl Environ Microbiol 71:2162-2169. doi: 10.1128/ AEM.71.4.2162-2169.2005

Torres-Bacete J, Hormigo D, TorresGúzman R, Arroyo M, Castillón MP, García L, Acebal C, de la Mata I (2015) Overexpression of penicillin V acylase from Streptomyces lavendulae and elucidation of Its catalytic residues. Appl Environ Microbiol 81:1225-1233. doi: 10.1128/AEM.02352-14

Widenfalk A (2005) Interactions between pesticides and microorganisms in freshwater sediments - Toxic effect and implications for bioavailability. Thesis, Swedish University of Agricultural Sciences

Yamamura H, Hayakawa M, Nakagawa Y, limura $Y$ (2003) Species diversity of Nocardiae isolated from lake and moat sediment samples. Actinomycetologica 17:44-46. doi: 10.3209/saj.17_44 